Article

\title{
Biocementation of Calcareous Beach Sand Using Enzymatic Calcium Carbonate Precipitation
}

\author{
Ahmed Miftah ${ }^{1, * \mathbb{D}}$, Hamed Khodadadi Tirkolaei ${ }^{2}$ and Huriye Bilsel ${ }^{1}$ \\ 1 Department of Civil Engineering, Cyprus International University, Nicosia 99258, Cyprus; hbilsel@ciu.edu.tr \\ 2 Center for Bio-mediated and Bio-inspired Geotechnics (CBBG), Arizona State University, \\ Tempe, AZ 85287-3005, USA; hkhodada@asu.edu \\ * Correspondence: ahmadmiftha88@gmail.com or amiftah@ciu.edu.tr
}

Received: 6 September 2020; Accepted: 28 September 2020; Published: 1 October 2020

check for updates

\begin{abstract}
Beach sands are composed of a variety of minerals including quartz and different carbonate minerals. Seawater in beach sand contains several ions such as sodium, magnesium, calcium, chloride, sulfate, and potassium. These variations in mineralogy and the presence of salts in beach sand may affect the treatment via enzyme-induced carbonate precipitation (EICP). In this study, set test tube experiments were conducted to evaluate the precipitation kinetics and mineral phase of the precipitates in the presence of zero, five, and ten percent seawater $(v / v)$. The kinetics were studied by measuring electrical conductivity (EC), $\mathrm{pH}$, ammonium concentration, and carbonate precipitation mass in EICP solution at different time intervals. A beach sand was also treated using EICP solution containing zero and ten percent seawater at one, two, and three cycles of treatment. Unconfined compressive strength (UCS), carbonate content, and mineralogy of the precipitates in the treated specimens were evaluated. The kinetics study showed that the rate of urea hydrolysis and the rate of precipitation for zero, five, and ten percent seawater were similar within the first $16 \mathrm{~h}$ of the reaction. After $16 \mathrm{~h}$, it was observed that the rates dropped in the solution containing seawater, which might be attributed to the faster decay rate of urease enzyme when seawater is present. All the precipitates from the test tube experiments contained calcite and vaterite, with an increase in vaterite content by increasing the amount of seawater. The presence of ten percent seawater was found to not significantly affect the UCS, carbonate content, and mineralogy of the precipitates of the treated beach sand.
\end{abstract}

Keywords: biocementation; EICP; calcium carbonate; beach sand

\section{Introduction}

Enzyme-induced carbonate precipitation (EICP) is an emerging biologically-based ground improvement technique that precipitates calcium carbonate within the pores of a granular soil via hydrolysis of urea catalyzed by free urease enzyme. Calcium carbonate $\left(\mathrm{CaCO}_{3}\right)$ can cement the soil particles by precipitating at the particle-to-particle contact points or increase the particle roughness by precipitating at the particle surface. EICP has been studied for different applications, such as strengthening granular soil [1-7], reducing the hydraulic conductivity of granular soil [8-10], fugitive dust mitigation [11-13], sealing cracks in concrete [14], and removal of heavy metal ions [15].

Despite many studies on using microbially induced calcite precipitation MICP and EICP for soil improvement, there are only a few MICP studies using this technique for the treatment of beach sand [16-23]. Shanahan and Montoya [16] created a bench model simulating a coastal sand dune using a clean fine sand, typical of coastal dune deposits. They applied MICP treatment to the sand dune model and then assessed the resistance of the model to erosion under simulated wave actions. They reported that the samples treated with MICP had high resistance to erosion as compared to untreated 
soil. The angle of repose of the treated sand increased remarkably as well. Daryono et al. [22] studied the feasibility of constructing artificial beach rocks using MICP and beach sand as a proposed method for coastal protection against water erosion. The results indicated that artificial bedrocks have an unconfined compressive strength of up to around six $\mathrm{MPa}$. This study, however, did not address the effect of seawater on precipitation efficiency. Other studies using EICP for soil strengthening, except for Oliveira et al. [24], who evaluated the effect of organic matter content on the efficiency of EICP that used clean base sands with no or insignificant amount of fines content and salts. No study was performed to explore EICP treatment of beach sands.

Beach sands are composed of a variety of minerals including quartz, feldspar, and different carbonate minerals. They also contain pore seawater, which contains several ions such as sodium $\left(\mathrm{Na}^{+}\right)$, magnesium $\left(\mathrm{Mg}^{2+}\right)$, calcium $\left(\mathrm{Ca}^{2+}\right)$, chloride $\left(\mathrm{Cl}^{-}\right)$, sulfate $\left(\mathrm{SO}_{4}{ }^{2-}\right)$, and potassium $\left(\mathrm{K}^{+}\right)$. These variations in mineralogy and the presence of seawater can affect soil treatment via MICP and EICP. Bacterial cell attachment to soil particles surface can be affected by soil mineralogy [25]. Pre-existing carbonate particles (such as shell fragments) can act as homogenous nucleation points for carbonate precipitation. It was reported by van Paassen [26] that different morphologies exist of calcium carbonate between the precipitates on the surface of carbonate particle and the surface of quartz sand particles. Presence of seawater can also influence the morphology of the precipitates. It results in co-precipitation of various inorganic compounds depending on its composition, salinity, and temperature [27-29]. An increase in ionic strength (salinity) may increase the rate of calcium carbonate precipitation [28]. Natural inorganic seawater constituents, especially magnesium and sulfate ions, hinder calcite precipitation at a given ionic strength $[27,28]$. It is well known that morphology of microbial $\mathrm{CaCO}_{3}$ in seawater is mainly controlled by the $\mathrm{Mg}$ :Ca ratio in seawater [30]. Contrary to calcium ions, magnesium ions stabilize unstable, hydrated, and amorphous phases [31]. The adsorption and incorporation of foreign ions like magnesium into a biogenic calcite crystal structure are significantly correlated with temperature and total ionic strength of parent solution [28,29,32]. This may affect the mineralogy of $\mathrm{CaCO}_{3}$ by inhibiting the formation of rhombohedral calcite crystals [32]. Khodadadi Tirkolaei [33] demonstrated the change in morphology of the microbially-induced calcium carbonate precipitates in the presence of seawater. He showed that aragonite precipitated together with calcite in MICP solution containing seawater. Seawater might be also used as a source of calcium for the biologically-induced calcium carbonate precipitation [34]. Salinity of seawater may also affect the chemical efficiency of microbially- and enzyme-induced carbonate precipitation [4,33]. High ionic strength of solution may also lead to precipitation of enzyme proteins (i.e., salt out) [35]. Due to the scarcity of previous studies considering the applicability of using EICP in the marine environment, the current study aimed to evaluate applying this technique to the strengthening of calcareous beach sand and exploring the effects of seawater on the efficiency and mineralogy of the enzymatic calcium carbonate precipitations.

\section{Materials and Methods}

\subsection{Beach Sand}

The sand used in this study was natural beach sand obtained from Famagusta Bay, North Cyprus. The particle size distribution parameters $\left(D_{10}, D_{50}, C_{u}\right.$, and $\left.C_{c}\right)$ were obtained using the standard test method for particle-size distribution of soils by dry sieving test, using a set of standard sieves and a mechanical sieve shaker (ASTM D6913) [36]. The minimum and maximum void ratios have been calculated according to JIS A1224 [37], and the $\mathrm{CaCO}_{3}$ percentage was quantified as described in Section 2.3. The beach sand was classified according to the Unified Soil Classification System (USCS) [38]. Table 1 illustrates the basic geotechnical properties of the sand. 
Table 1. Physical properties of sand.

\begin{tabular}{cc}
\hline Property & Value \\
\hline Effective diameter, $\mathrm{D}_{10}$ & 0.14 \\
Median diameter, $\mathrm{D}_{50}$ & 0.7 \\
Uniformity coefficient, $\mathrm{C}_{\mathrm{u}}$ & 6.42 \\
Coefficient of curvature, $\mathrm{C}_{\mathrm{c}}$ & 1.4 \\
Minimum void ratio $\left(\mathrm{e}_{\min }\right)$ & 0.562 \\
Maximum void ratio $\left(\mathrm{e}_{\max }\right)$ & 0.880 \\
$\mathrm{CaCO}_{3}(\%)$ & 62.50 \\
Specific Gravity, $\mathrm{G}_{\mathrm{s}}$ & 2.70 \\
USCS Classification & $\mathrm{SP}$ \\
\hline
\end{tabular}

\subsection{Aqueous Medium Experiments}

\subsubsection{Enzyme Concentration Determination}

Test tube experiments were conducted to determine the appropriate concentration of enzyme yielding a higher mass of precipitation. For this purpose, EICP solution containing $1 \mathrm{M}$ urea, $0.67 \mathrm{M}$ calcium chloride anhydrous, $4 \mathrm{~g} / \mathrm{L}$ non-fat dry milk powder, and different concentrations $(15 \mathrm{~mL} / \mathrm{L}$, $11 \mathrm{~mL} / \mathrm{L}, 10 \mathrm{~mL} / \mathrm{L}, 5 \mathrm{~mL} / \mathrm{L}, 2.5 \mathrm{~mL} / \mathrm{L}$, and $1.25 \mathrm{~mL} / \mathrm{L}$ ) of crude urease extract (with urease activity of $\approx 465 \mathrm{U} / \mathrm{mL}$ ) were prepared in 50 -mL test tubes. The substrates concentration was selected based on Almajed et al. [4]. The urease enzyme was crudely extracted from sword jack bean (Canavalia Gladiata) according to the method of Khodadadi Tirkolaei et al. [39]. Activity of the urease enzyme was determined using Nessler's reagent as described by Khodadadi Tirkolaei et al. [36]. Each tube was cured at room temperature for 4 days. After curing, each tube was centrifuged at $3500 \mathrm{rpm}$ for $5 \mathrm{~min}$ and the supernatant was discarded. The remaining precipitates were rinsed twice by adding $30 \mathrm{~mL}$ distilled water. After each rinsing, supernatant was removed via centrifugation at $3500 \mathrm{rpm}$ for $5 \mathrm{~min}$. Finally, the precipitates were dried at $50{ }^{\circ} \mathrm{C}$ until constant mass achieved. The mass of precipitates in each tube was measured by subtracting the mass of each empty tube from the mass of the tube after the final centrifugation. All the tests were conducted in triplicate. At the end, the enzyme concentration resulting in the highest calcium carbonate precipitation ratio (Pr) was selected for beach sand treatment. Precipitation ratio was defined as the precipitation mass over the theoretical maximum precipitation that can be stoichiometrically obtained.

\subsubsection{Kinetics of EICP in Presence of Seawater}

EICP solutions were prepared at two different concentrations of seawater $(5 \%$ and $10 \%(v / v))$. Salinity and composition of the seawater are presented in Table 2. Electrical conductivity (EC) and pH of the EICP solutions were measured at different time intervals $(0,0.5,1,2,4,8,16,32,48$, and $72 \mathrm{~h}$ ), using a Thermo Orion 3-star $\mathrm{pH}$ meter and WTW EC meter. The $\mathrm{pH}$ and conductivity meters were both calibrated prior to each set of measurements. Rate of carbonate precipitation was determined by measuring the mass of precipitation at the same time intervals and in the same way as explained in Section 2.2.1. Rate of urea hydrolysis in each tube was also estimated using direct colorimetric determination of ammonium using Nessler's reagent (each one mole of hydrolyzed urea will liberate 2 moles of ammonium). In this method, $1 \mathrm{~mL}$ of EICP solution was taken at different times (the same time intervals as indicated above) and added into $99 \mathrm{~mL}$ DI water (i.e., 100 times dilution). Then, $2 \mathrm{~mL}$ of the diluted solution was poured into a cuvette containing $100 \mu \mathrm{L}$ Nessler's reagent. After $2 \mathrm{~min}$, the cuvette was placed in a spectrophotometer (Shimadzu-UV-2450) to measure the color absorbance at $410 \mathrm{~nm}$. The same measurements were performed for seawater-free EICP solution (i.e., EICP solution with $0 \%$ seawater) as a baseline solution. All the tests were conducted in triplicate. 
Table 2. Major ions concentrations, $\mathrm{pH}$ and electrical conductivity of the seawater.

\begin{tabular}{cc}
\hline Ingredient & Seawater \\
\hline $\mathrm{Cl}^{-}$ & $28200 \mathrm{ppm}$ \\
$\mathrm{Na}^{+}$ & $26250 \mathrm{ppm}$ \\
$\mathrm{SO}_{4}^{2-}$ & $5150 \mathrm{ppm}$ \\
$\mathrm{Mg}^{2+}$ & $7100 \mathrm{ppm}$ \\
$\mathrm{K}^{+}$ & $461 \mathrm{ppm}$ \\
$\mathrm{Ca}^{2+}$ & $400 \mathrm{ppm}$ \\
$\mathrm{pH}$ & 6.7 \\
$\mathrm{EC}$ & $63.3 \mathrm{mS} / \mathrm{cm}$ \\
\hline
\end{tabular}

\subsection{Beach Sand Treatment}

Eighteen sand columns of 5-cm diameter and 10-cm height were treated in PVC tubes using two different EICP solutions of $0 \%$ (baseline solution) and 10\% (v/v\%) seawater at one, two, and three cycles of treatment. Each treatment condition was conducted in triplicate. Then, $267 \mathrm{~g}$ of beach sand was poured into each tube in three equal layers, each layer being tamped slightly from four sides to achieve a relative density of $60 \%$. One pore volume of treatment solution (i.e., $68 \mathrm{~mL}$ of EICP solution) was percolated through the columns at each cycle. The samples were cured for 4 days per treatment cycle at room temperature. After curing, each column was stirred in a water bath for 2 min and soaked for two hours, in order to remove soluble compounds. After washing, specimens were oven-dried at $50{ }^{\circ} \mathrm{C}$ until a constant mass was achieved and then leveled by gently polishing the surface with sandpaper and a mini spirit level. An unconfined compressive strength test was performed to measure the strength of each treated sand column. A strain rate of $1 \mathrm{~mm} / \mathrm{min}$ was applied for all UCS tests.

Carbonate content of the treated specimens was measured by gravimetric acid digestion. In this method, three $20-\mathrm{g}$ chunks of each specimen were separately soaked in $100 \mathrm{~mL}$ of $1 \mathrm{M}$ hydrochloric acid $(\mathrm{HCl})$ solution. The sand suspension was stirred until no seething was observed. Ten $\mathrm{mL}$ of acid solution was added into the beaker under stirring. This step was repeated until the seething stopped. The suspension was left for $3 \mathrm{~h}$ until the sediment completely settled at the bottom of the beaker and then the acid solution was collected using a 50-mL syringe with minimal agitation. Following this, $400 \mathrm{~mL}$ of distilled water was added into the beaker and stirred, and then left to settle again for $2 \mathrm{~h}$. After collecting the water using a 50-mL syringe, this step was repeated more times. In the end, the beaker containing the wet sand was put into an oven at $50{ }^{\circ} \mathrm{C}$ until a constant mass was achieved. To determine the mass of precipitation obtained by EICP treatment, the non-treated sand was also digested in $\mathrm{HCl}$ and its carbonate content was subtracted from the carbonate content of the treated specimens. The mass of enzyme-induced precipitates over the dry mass of sand was reported as enzymatic carbonated content.

\subsection{Microscale Identification}

Scanning electron microscopy (SEM) JEOL JSM-6610LV was employed to observe the beach sand particles before and after EICP treatment. The samples were coated with carbon using SC7620 Mini Sputter Coater. Crystal phase of the sand particles and the precipitates were identified using X-ray powder diffraction analysis (Rigaku Ultima iv $\mathrm{X}$-ray powder diffractometer) with $\mathrm{Cu}-\mathrm{K} \alpha$ radiation (40 kV and $30 \mathrm{~mA}$ ) and a scanning speed of $2^{\circ} / \mathrm{min}$, which ranges from $10-90^{\circ} 2 \theta$. All samples were thoroughly ground and passed through a number 50 sieve. The Fourier-transform infrared spectroscopy (FTIR, Spectrum Two, PerkinElmer) was also used to determine if the precipitates contain amorphous calcium carbonate.

The following equation was used to quantify calcite and vaterite content of each precipitate using its XRD spectrum [40]:

$$
X_{C}=X_{V} \frac{I_{C}}{I_{V} \times 4.0}
$$


where $X_{C}$ and $X_{V}$ are the mole fraction of calcite and vaterite, respectively. $I_{C}$ and $I_{V}$ are the integrated intensity for a selected peak at $2 \theta=29.5^{\circ}$ for calcite, $2 \theta=25.0^{\circ}$ for vaterite. The integration of peak intensity was calculated by OriginPro (2018) software. This method is used for the precipitate that comprises of only calcite and vaterite crystal phases (i.e., $X_{C}+X_{V}=1$ ).

\section{Results}

\subsection{Aqueous Medium Experiments}

Table 3 shows the results of test tube experiments for enzyme concentration determination. As shown, mass of precipitation and precipitation ratio increased by increasing the enzyme concentration to $10 \mathrm{~mL} / \mathrm{L}$ above which no significant increase in precipitation mass and ratio was observed. Therefore, enzyme concentration of $10 \mathrm{~mL} / \mathrm{L}$, which is equivalent to $4650 \mathrm{U} / \mathrm{L}$, was selected for EICP solution preparation in the aqueous medium and beach sand treatment experiments in this study. This result is consistent with Neupane et al. [8] and Almajed et al. [4] who reported a similar pattern of precipitation ratio versus enzyme concentration.

Table 3. Results of test tube experiments.

\begin{tabular}{ccccc}
\hline & & & & \multicolumn{2}{c}{ Precipitation Efficiency * } \\
\cline { 3 - 5 } Tube No. & Enzyme Concentration, $\mathbf{m L} / \mathbf{L}$ & Enzymatic $\mathrm{CaCO}_{3}$ Mass, $\mathbf{~}$ & Efficiency, \% & Mean, STD \\
\hline T1 & 1.25 & 1.213 & 36.32 & \\
T2 & 1.25 & 1.119 & 33.50 & $33.53-2.76$ \\
T3 & 1.25 & 1.028 & 30.78 & \\
T4 & 2.5 & 1.334 & 39.94 & \\
T5 & 2.5 & 1.384 & 41.44 & $42.81-3.75$ \\
T6 & 2.5 & 1.572 & 47.07 & \\
T7 & 5 & 2.154 & 64.49 & \\
T8 & 5 & 2.167 & 64.88 & \\
T9 & 5 & 2.129 & 63.74 & \\
T10 & 10 & 3.022 & 90.48 & \\
T11 & 10 & 2.956 & 88.50 & $90.12-1.167$ \\
T12 & 10 & 3.025 & 90.57 & \\
T13 & 11 & 2.898 & 86.77 & \\
T14 & 11 & 2.951 & 88.35 & \\
T15 & 11 & 2.891 & 86.56 & \\
T16 & 15 & 2.894 & 86.65 & \\
T17 & 15 & 2.901 & 86.86 & $85.89-1.49$ \\
T18 & 15 & 2.811 & 84.16 & \\
\hline
\end{tabular}

* Precipitation efficiency: precipitation mass over the theoretical maximum precipitation, which can be stoichiometrically obtained.

Kinetics of reaction in EICP solutions with $0 \%, 5 \%$, and $10 \%(v / v)$ seawater was monitored by measuring ammonium concentration, precipitation mass, $\mathrm{pH}$, and $\mathrm{EC}$ at different time intervals. Figure 1 shows ammonium concentration and EC versus time. As shown, the rate of ammonium production (i.e., urea hydrolysis) in the three solutions are similar until around $32 \mathrm{~h}$ after beginning the reactions, beyond which the rate drops faster in the solutions containing a higher concentration of seawater. The lower rate of urea hydrolysis in the solutions containing seawater after $32 \mathrm{~h}$ can indicate a faster rate of decay of the urease enzyme in the presence of the seawater, which caused an increase in the ionic strength of the EICP solution. EC measurements demonstrated the higher ionic strength of EICP solutions containing seawater during the reactions. The increase in EC also verifies ammonium production in each solution; however, the rate of increase in EC did not precisely represent the rate of urea hydrolysis as EC measurement gives only an indication of the ammonium ion concentration in the solution and not the ammonia off-gassed from the solution due to $\mathrm{pH}$ increase. 


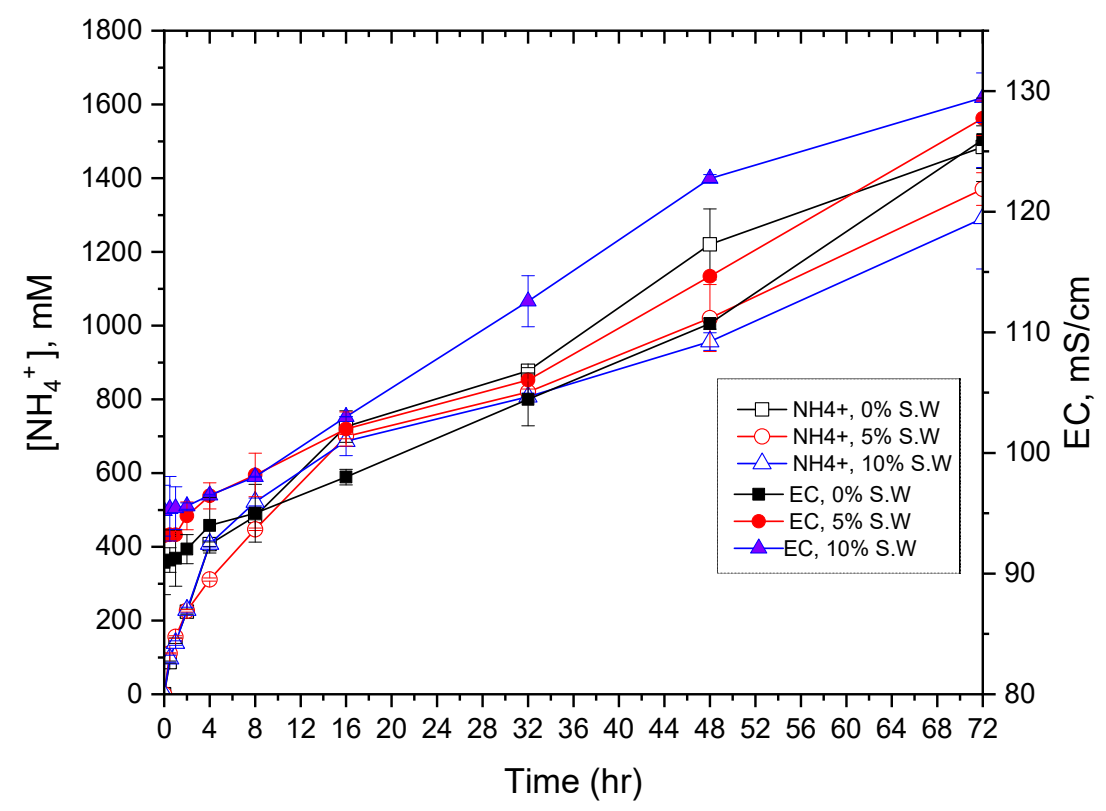

Figure 1. Comparison between electrical conductivity and ammonium concentration at different time durations.

Figure 2 shows that the change in the amount of precipitation occured in a similar pattern as urea hydrolysis versus time. As shown, the final amount of precipitation and the precipitation ratio decreased when the concentration of seawater in EICP solution increased. This can also be attributed to the decay of enzyme in the presence of seawater, resulting in an incomplete hydrolysis of urea and consequently a smaller amount of precipitation. Figure 3 shows the change in $\mathrm{pH}$ of each solution during the precipitation reactions. It was observed that the initial $\mathrm{pH}$ of $6.6-6.8$ spiked to 8.5-8.8 after the addition of an enzyme into the substrate solution. This sudden increase in the $\mathrm{pH}$ was because of the fast rate of urea hydrolysis at the beginning of the reaction until the solution become supersaturated. When the first nucleation occured at supersaturation, the $\mathrm{pH}$ drops to below 8 until all the calcium ions were consumed. Van Paassen [26] reported a similar $\mathrm{pH}$ pattern for microbially-induced carbonate precipitation.

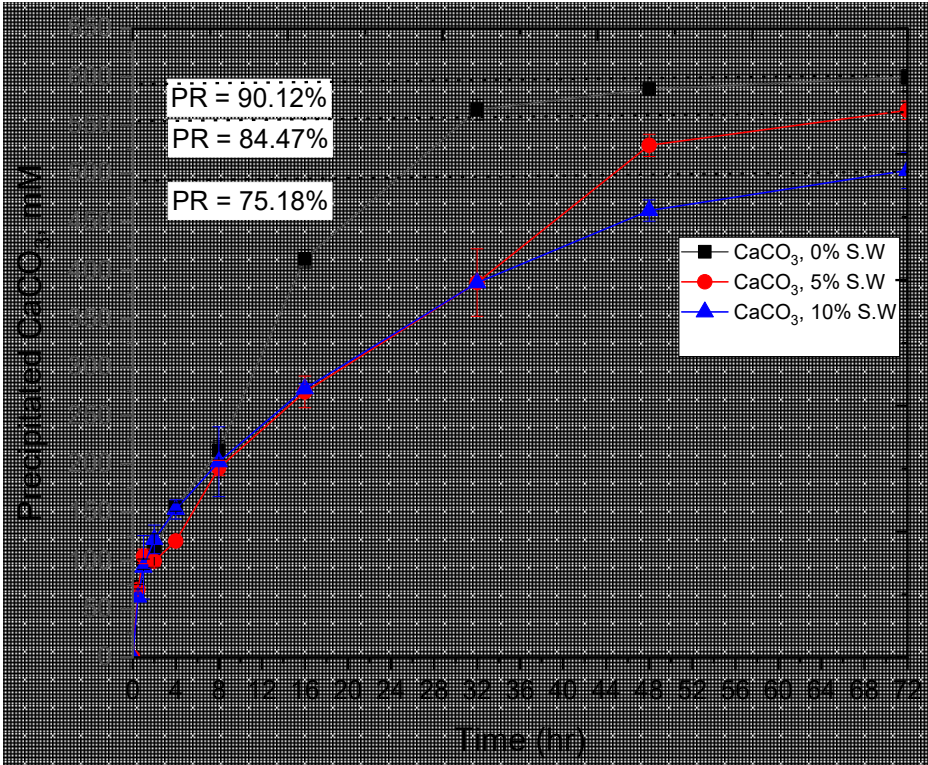

Figure 2. Precipitated calcium carbonate ions at different time durations (dashed line showing the chemical efficiency PR\%). 


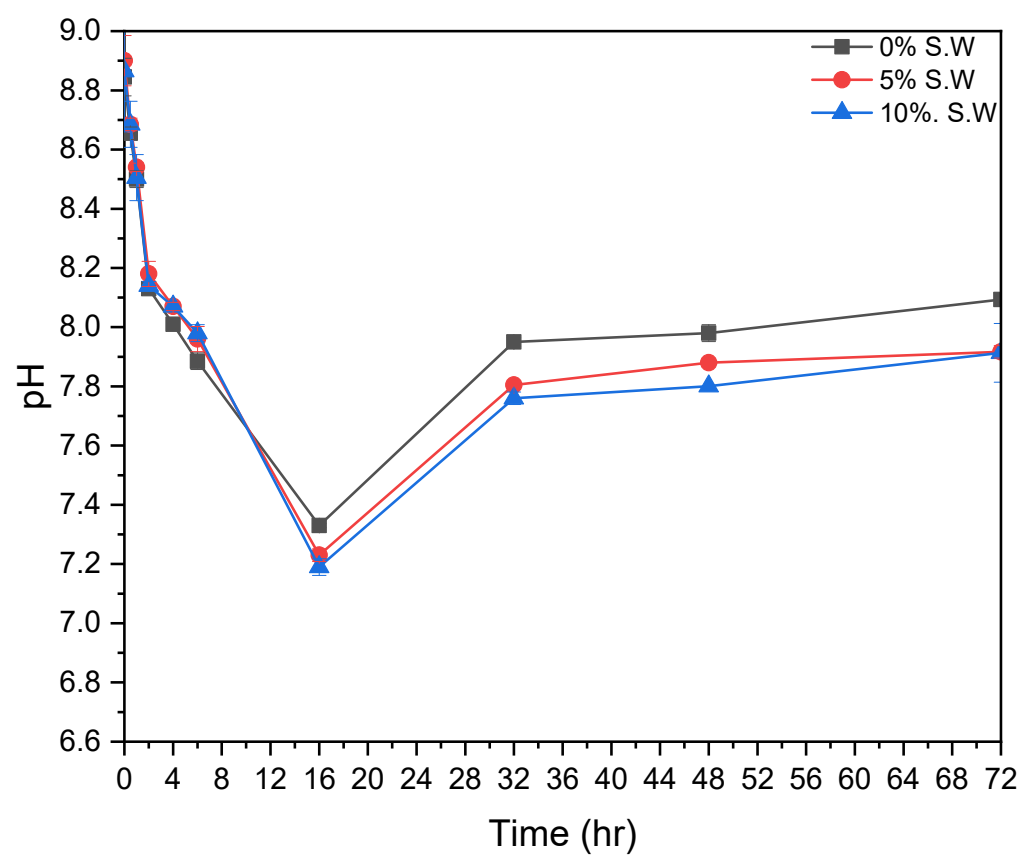

Figure 3. $\mathrm{pH}$ values of calcium carbonate precipitation.

Mineralogy of the precipitates obtained from EICP solution containing $0 \%, 5 \%$, and $10 \%(v / v)$ seawater were also examined. As shown in Figure $4 \mathrm{a}$, the precipitates obtained from the three solutions contained calcite and vaterite crystal phases. Presence of vaterite in the plain EICP solution (i.e., $0 \%$ seawater) can be ascribed to the organic compounds of milk and crude urease extract [39]. The amount of vaterite in the precipitates increased by increasing the concentration of seawater. This increase in vaterite concentration can be attributed to the effect of inhibiting ions coming from seawater into EICP solution; for instance, magnesium and sulfate were reported to suppress formation rhombohedral calcite and stabilize vaterite in a calcium carbonate precipitation system [41,42]. FTIR spectra verifies the presence of calcite and vaterite in the precipitates obtained from the three solutions (see Figure $4 \mathrm{~b}$ ). It shows the characteristic peaks of calcite (i.e., 713 and $874 \mathrm{~cm}^{-1}$ ) and vaterite (i.e., 744,876 , and $1087 \mathrm{~cm}^{-1}$ ) [43]. No peaks associated with the presence of amorphous calcium carbonate were identified. SEM micrographs in Figure 5 illustrate the morphology of the precipitates from each solution. As shown, the precipitates mainly contain agglomerates of spherical crystals and poorly developed rhombohedral crystals. The spherical crystals can be attributed to spherical calcite and vaterite. 


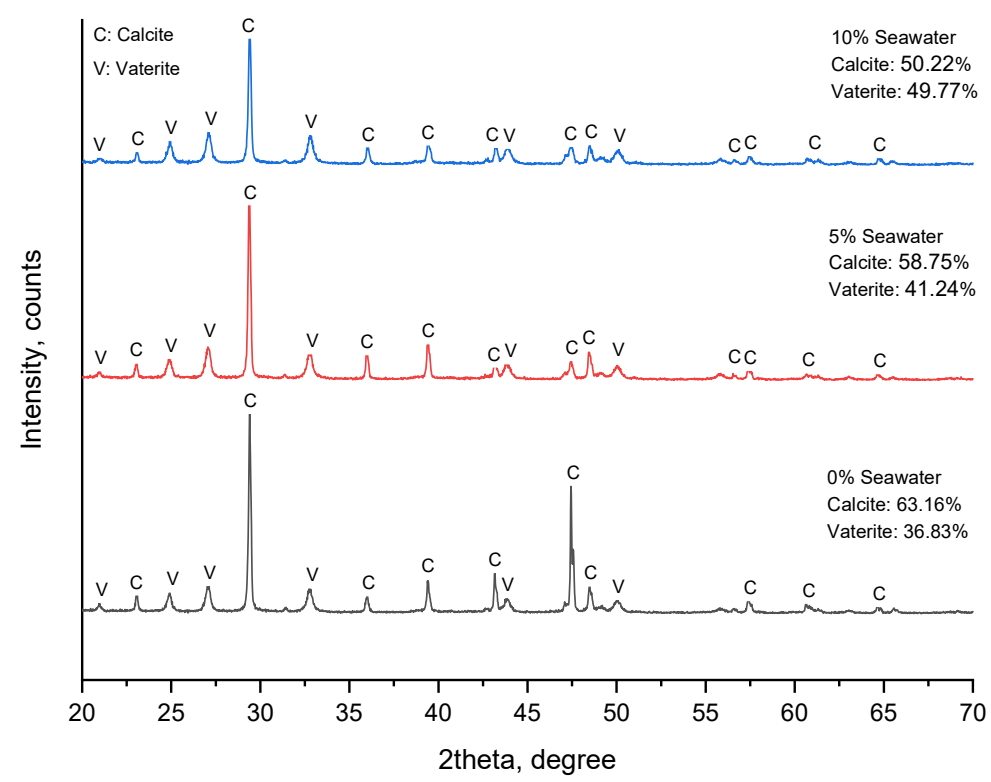

(a)

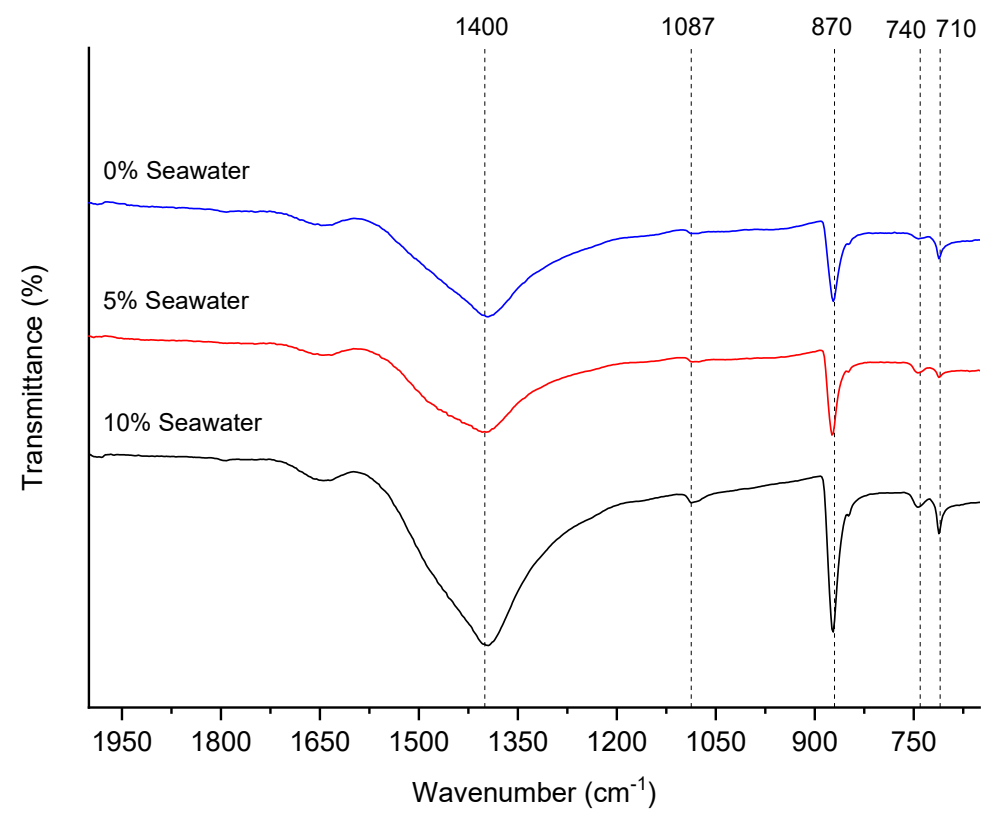

(b)

Figure 4. The enzymatic $\mathrm{CaCO}_{3}$ precipitates obtained from a test tube for (a) XRD patterns and (b) FTIR patterns. 


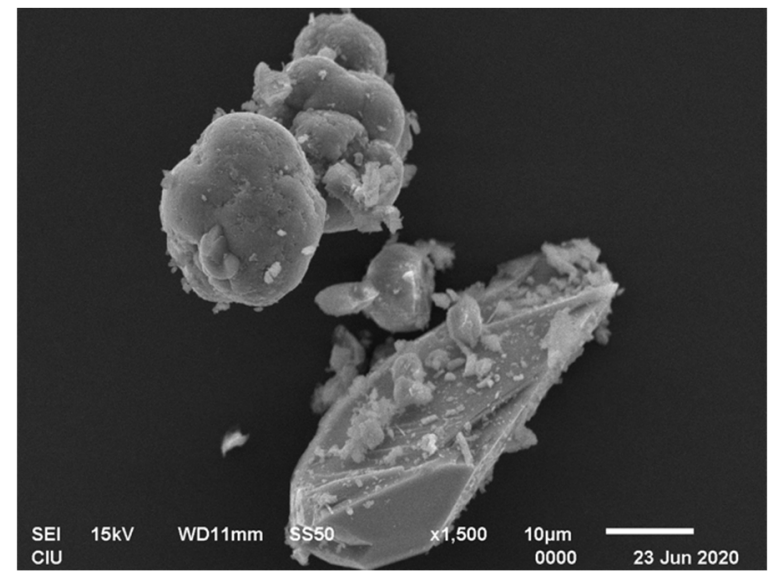

(a)

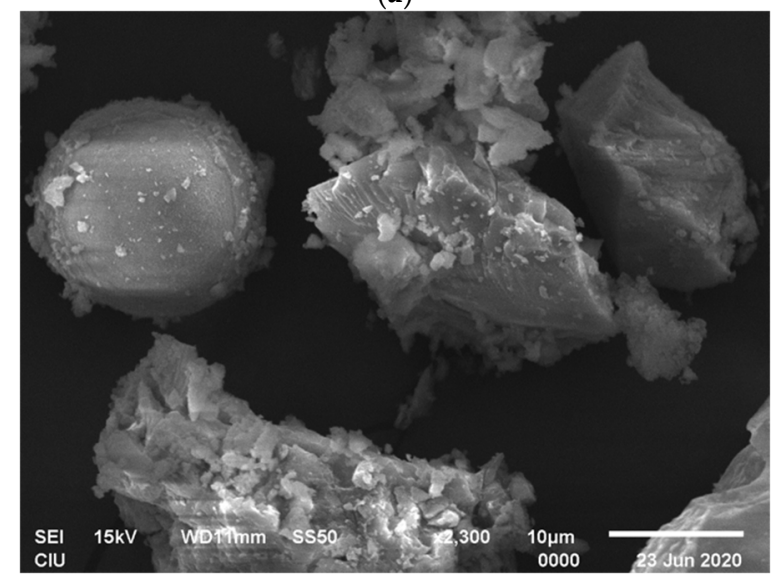

(b)

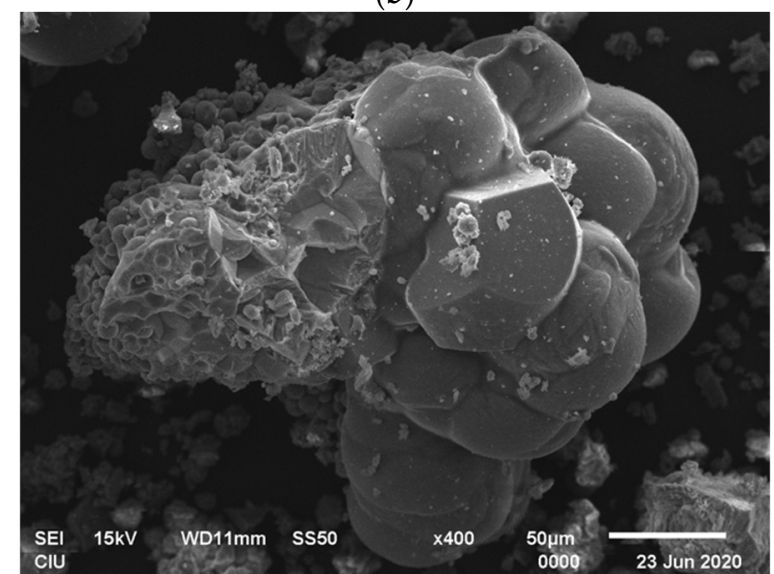

(c)

Figure 5. SEM micrographs of enzymatic $\mathrm{CaCO}_{3}$ precipitates: (a) $0 \%$ of $\mathrm{S} . \mathrm{W}(\mathbf{b}) ; 5 \%$ of seawater; (c) $10 \%$ of seawater.

\subsection{EICP Treatment of Beach Sand}

The UCS and carbonate content corresponding to each test condition $(0 \%$ and $10 \%$ seawater of $v / v$ EICP solution) and different treatment cycles are plotted in Figure 6a,b. As expected, carbonate content and consequently UCS of the treated specimens increased with increasing the number of treatment cycles for both $0 \%$ and 10\% seawater. The schematic in Figure 7 illustrates how increasing the number of treatment cycles may result in the $\mathrm{CaCO}_{3}$ bond formation between sand particles. For $0 \%$ seawater, with increase in the number of treatment cycles from one to three, the average carbonate content increased from 2 to $3.7 \%$, respectively, whereas for $10 \%$ seawater the corresponding average 
carbonate content increased from 1.95 to $3 \%$ respectively. Although it was theoretically expected to observe a higher carbonate content in the presence of seawater as seawater adds an additional calcium ions and other cations into the EICP solution, the less average carbonate content for $0 \%$ seawater may be attributed to the faster decay rate of urease enzyme in the presence of seawater as shown in the previous section. At the end of three cycles of treatment, for $0 \%$ seawater, the average UCS of around $0.263 \mathrm{MPa}$ was obtained (Figure 6a), whereas the average UCS of $0.224 \mathrm{MPa}$ was achieved for $10 \%$ seawater. However, considering the standard deviation of the measurements, no statistically significant difference between the carbonate content and UCS of the treated specimens at $0 \%$ and $10 \%$ seawater was observed.

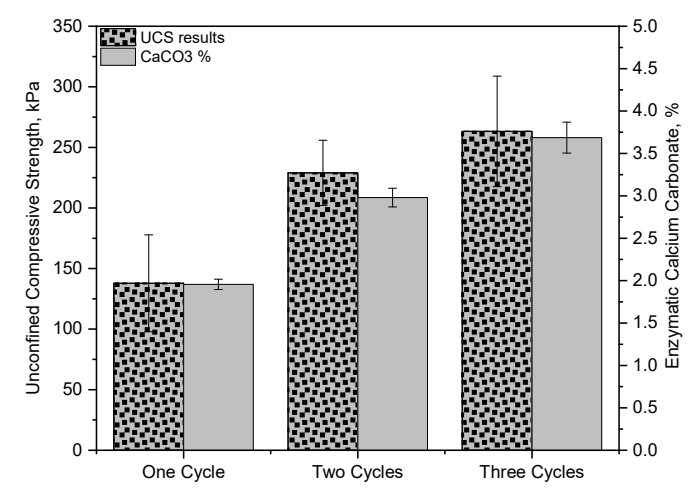

(a)

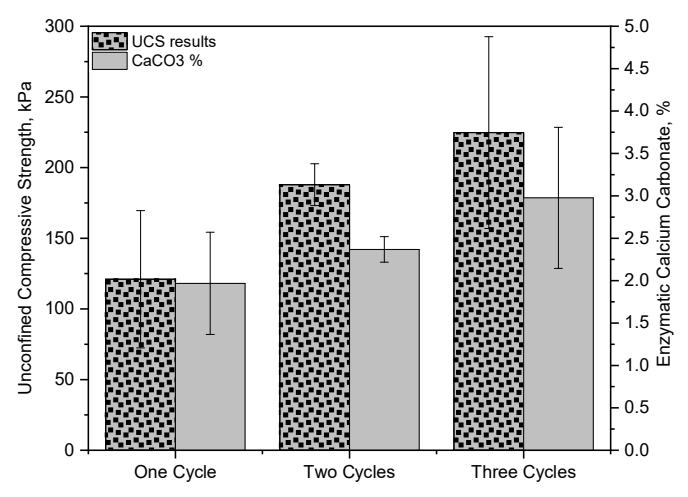

(b)

Figure 6. Beach sand treatment results of unconfined compressive strength and enzymatic carbonate content per treatment cycle (a) treated with enzyme-induced carbonate precipitation (EICP) solution prepared with distilled water only (b) by adding $10 \%$ seawater to the EICP solution $(v / v)$.

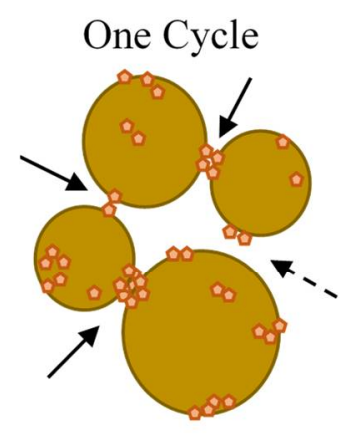

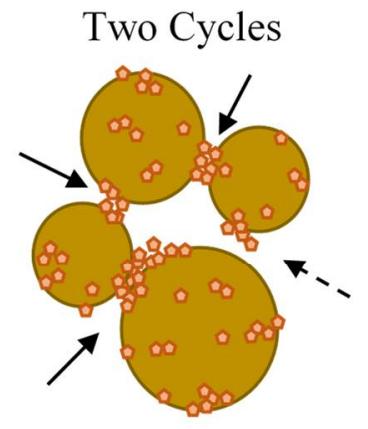

$\mathrm{CaCO}_{3}$ precipitates

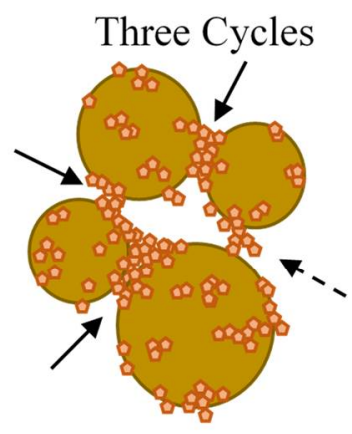

Sand grain

Figure 7. Schematic illustration of inter-particle binding at different cycles of treatment (solid arrows point out the bonds, which become stronger after each cycle and dashed arrows point out the bond development between particles with a higher inter-particle distance) [7].

XRD of the treated specimens are presented in Figure 8. As shown, except for the precipitates deposited on the surface of the treated specimens, the mineral phases detected in the body of the treated specimens for both $0 \%$ and $10 \%$ seawater were the same as non-treated beach sand. The beach sand used in the present study contains calcite as well as quartz, which makes it hard to distinguish the pre-existing calcite from the enzyme-induced calcite precipitates in the treated specimens using XRD. However, the lack of peaks corresponding to other phases of calcium carbonate (e.g., aragonite and vaterite) in the samples taken from the body of the treated specimens indicates that calcite was the predominant crystal phase of the enzyme-induced precipitation in the treated specimens. Detection of vaterite in the XRD of the precipitates deposited on the surface of the treated specimens is attributed to the vaterite minerals 
formed in the treatment solution standing on the sand surface in the treatment columns (see Figure 9). The level of treatment solution added into each column was slightly above the sand surface during these experiments. Presence of vaterite was also demonstrated in the precipitates obtained from EICP solution in the test tube experiments (see Section 3.1). Khodadadi Tirkolaei et al. [39] also reported the same mineral phases for the enzymatic precipitates obtained from bulk solution and in the treated sand. These investigators reported that the presence of organic compounds with carboxyl, hydroxyl, and phosphate groups coming from urease enzyme and milk powder can suppress crystallization of calcite in the bulk solution, whereas the same compounds can promote calcite crystallization when they are adsorbed on a sand surface in the solution. Presence of pre-existing calcite crystals in the beach sand may also facilitate crystallization of calcite [44].

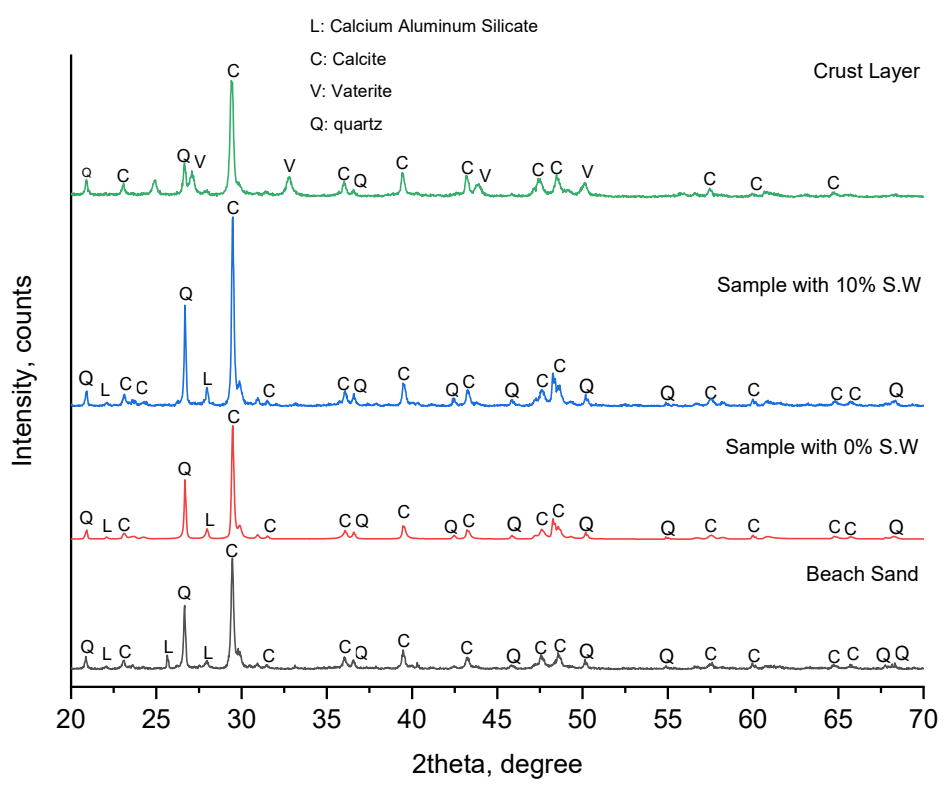

Figure 8. X-ray powder diffraction pattern of pure beach sand, cemented sand with $0 \%$ seawater EICP solution, cemented sand with 10\% seawater EICP solution, and the crust layer.

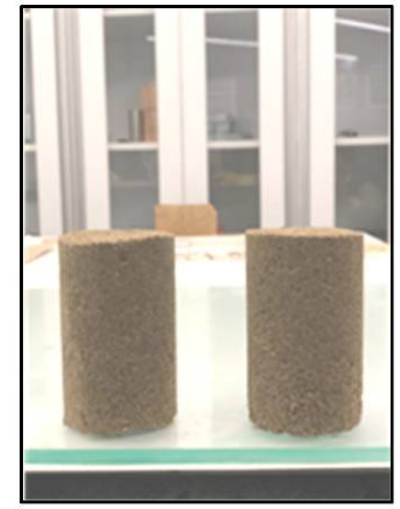

(a)

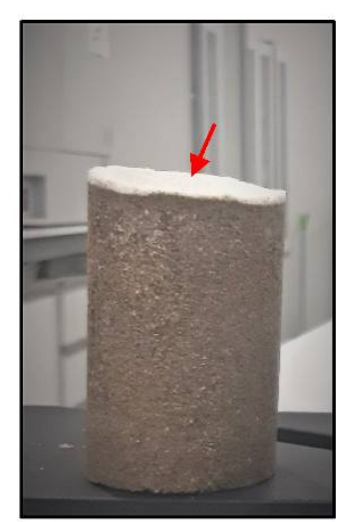

(b)

Figure 9. EICP-treated specimens: (a) one cycle treatment; (b) three cycles treatment (the arrow points out the precipitates deposited on the surface of the treated specimen).

Figure 10 shows the SEM images of the bare sand and the treated specimens. The precipitates were observed at inter-particle contacts and on particles' surfaces. The rhombohedral crystals in the treated specimens demonstrated the presence of calcite. 


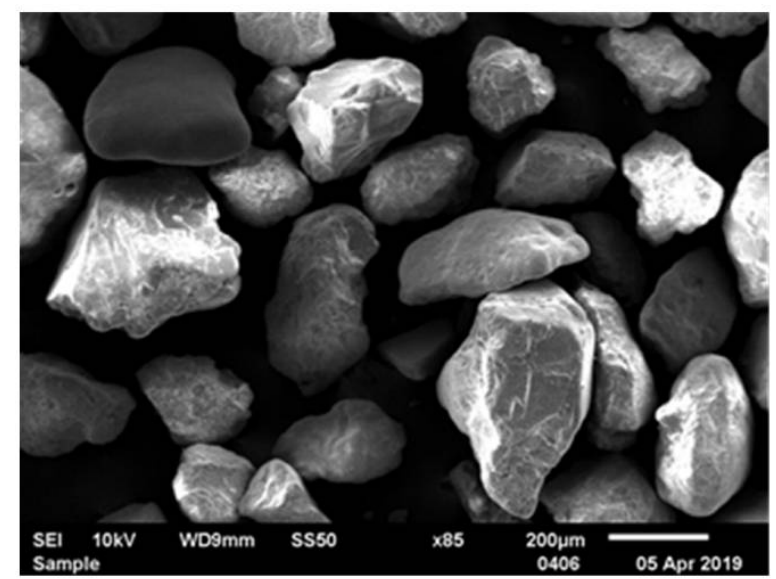

(a)

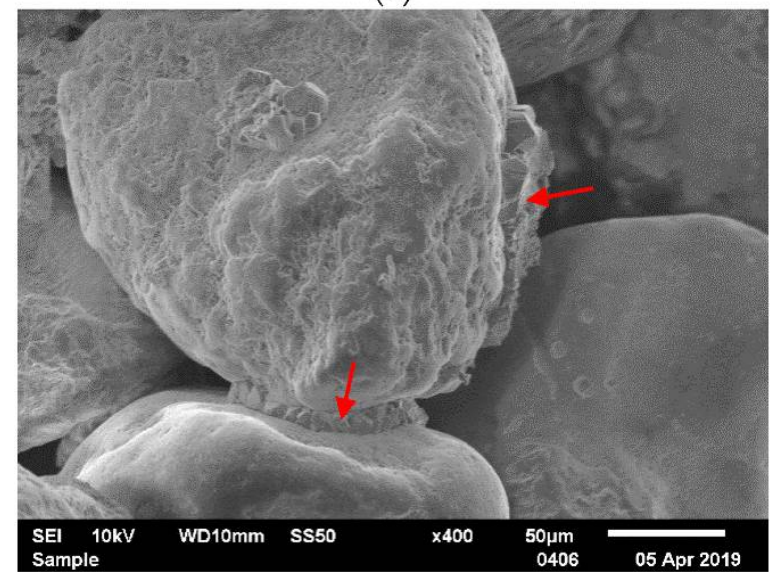

(b)

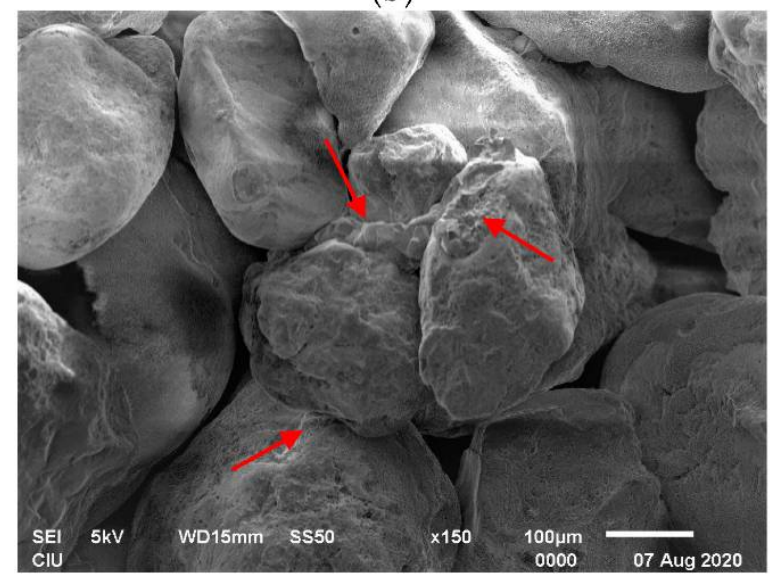

(c)

Figure 10. SEM micrographs of (a) pure beach sand, (b) cemented sand with $0 \%$ seawater EICP solution, (c) cemented sand with 10\% seawater EICP solution. (red arrows show the precipitated calcite minerals).

\section{Conclusions}

The study addressed the effects of seawater on the kinetics of EICP solution and strength of the bio-cemented beach sand. The results of the kinetic study revealed that the rate of urea hydrolysis and the rate of $\mathrm{CaCO}_{3}$ precipitation for zero, five, and ten percent seawater were similar within the first 16 $\mathrm{h}$ of the reaction. After $16 \mathrm{~h}$, it was observed that the rates dropped in the solution containing seawater, which might be attributed to the faster decay rate of urease enzyme when seawater was added. Calcite 
and vaterite crystal phases were identified in the precipitates obtained from all test-tube experiments. It was observed that the vaterite amount increased when seawater concentration increased, which can be attributed to the effect of inhibiting ions coming from seawater into an EICP solution. Presence of seawater was observed not to have a significant effect on the UCS, carbonate content, and mineralogy of the precipitates of the treated beach sand. At the end of three cycles of treatment, a strengthened average UCS of around $0.255 \mathrm{MPa}$ was obtained for the specimens treated with EICP solution containing no seawater, whereas about $0.224 \mathrm{MPa}$ was achieved for those treated with ten percent seawater. The XRD and SEM results of the treated beach sand showed the presence of calcite as the predominant crystal phase of the enzyme-induced carbonate precipitates in the treated specimens.

Author Contributions: Conceptualization, A.M., H.K.T., and H.B.; data curation, A.M.; formal analysis, A.M.; methodology, A.M. and H.K.T.; resources, H.B.; supervision, H.K.T. and H.B.; writing-original draft, A.M.; writing, review, and editing, H.K.T. and H.B. All authors have read and agreed to the published version of the manuscript.

Funding: This research received no external funding.

Acknowledgments: The authors wish to thank Hatice Erkurt for her valuable comments during the work and Ertan Akün for permitting the use of the facilities of the Operations and Environmental Engineering Laboratories at Cyprus International University.

Conflicts of Interest: The authors declare no conflict of interest regarding this study.

\section{References}

1. Yasuharaa, H.; Neupanea, D.; Hayashib, K.; Okamuraa, M. Experiments and predictions of physical properties of sand cemented by enzymatically-induced carbonate precipitation. Soils Found. 2012, 52, 539-549. [CrossRef]

2. Hamdan, N.; Kavazanjian, E.; O’Donnell, S. Carbonate Cementation via Plant Derived Urease. In Proceedings of the 18th International Conference on Soil Mechanics and Geotechnical Engineering, Paris, France, 2-5 September 2013; pp. 2-6.

3. Putra, H.; Yasuhara, H.; Kinoshita, N.; Hirata, A. Optimization of enzyme-mediated calcite precipitation as a soil-improvement technique: The effect of aragonite and gypsum on the mechanical properties of treated sand. Crystals 2017, 7, 59. [CrossRef]

4. Almajed, A.; Khodadadi Tirkolaei, H.; Kavazanjian, E., Jr. Baseline investigation on enzyme-induced calcium carbonate precipitation. Artic. J. Geotech. Geoenviron. Eng. 2018, 144. [CrossRef]

5. Pasillas, J.N.; Khodadadi Tirkolaei, H.; Martin, K.; Bandini, P.; Newtson, C.M.; Kavazanjian, E. Viscosity-Enhanced Eicp Treatment of Soil. In Geotechnical Special Publication; American Society of Civil Engineers (ASCE): Reston, VA, USA, 2018; pp. 145-154.

6. Miftah, A.; Khodadadi, T.H.; Bilsel, H. Strengthening Beach Sand by Enzyme Induced Calcium Carbonate Precipitation. In Proceedings of the 8th Geotechnical Symposium, Istanbul, Turkey, 13-15 November 2019; pp. 1-8.

7. Martin, K.K.; Khodadadi, T.H.; Kavazanjian, E., Jr. Enzyme-Induced Carbonate Precipitation: Scale-up of Bio-Cemented Soil Columns. In Geotechnical Special Publication; American Society of Civil Engineers (ASCE): Reston, VA, USA, 2020; pp. 96-103.

8. Neupane, D.; Yasuhara, H.; Kinoshita, N.; Unno, T. Applicability of enzymatic calcium carbonate precipitation as a soil-strengthening technique. J. Geotech. Geoenviron. Eng. 2013, 139, 2201-2211. [CrossRef]

9. Larsen, J.; Poulsen, M.; Lundgaard, T.; Agerbæk, M. Plugging of fractures in chalk reservoirs by enzymatic induced calcium carbonate precipitation. In Offshore Europe; Society of Petroleum Engineers (SPE): TX, USA, 2007; pp. 268-273.

10. Beser, D.; West, C.; Cunningham, A.; Fick, D.; Phillips, A.; Daily, R.; Gerlach, R.; Spangler, L. Assessment of Ureolysis Induced Mineral Precipitation Material Properties Compared to Oil and Gas Well Cements. In Proceedings of the 51st US Rock Mechanics/Geomechanics Symposium, San Francisco, CA, USA, 25-28 June 2017.

11. Hamdan, N.; Kavazanjian, E. Enzyme-induced carbonate mineral precipitation for fugitive dust control. Geotechnique 2016, 66, 546-555. [CrossRef] 
12. Woolley, M.A.; van Paassen, L.; Kavazanjian, E., Jr. Impact on surface hydraulic conductivity of eicp treatment for fugitive dust mitigation. In Geotechnical Special Publication; American Society of Civil Engineers (ASCE): Reston, VA, USA, 2020; pp. 132-140.

13. Wu, M.; Hu, X.; Zhang, Q.; Zhao, Y.; Sun, J.; Cheng, W.; Fan, Y.; Zhu, S.; Lu, W.; Song, C. Preparation and performance evaluation of environment-friendly biological dust suppressant. J. Clean. Prod. 2020, 273, 123162. [CrossRef]

14. Dakhane, A.; Das, S.; Hansen, H.; O’Donnell, S.; Hanoon, F.; Rushton, A.; Perla, C.; Neithalath, N. Crack healing in cementitious mortars using enzyme-induced carbonate precipitation: Quantification based on fracture response. J. Mater. Civ. Eng. 2018, 30, 04018035. [CrossRef]

15. Moghal, A.A.B.; Lateef, M.A.; Mohammed, S.A.S.; Lemboye, K.; Chittoori, B.C.S.; Almajed, A. Efficacy of enzymatically induced calcium carbonate precipitation in the retention of heavy metal ions. Sustainability 2020, 12, 7019. [CrossRef]

16. Shanahan, C.; Montoya, B.M. Strengthening coastal sand dunes using microbial-induced calcite precipitation. In Geo-Congress 2014 Technical Papers; American Society of Civil Engineers: Reston, VA, USA, 2014; pp. 1683-1692.

17. Cheng, L.; Shahin, M.A.; Cord-Ruwisch, R. Bio-cementation of sandy soil using microbially induced carbonate precipitation for marine environments. Géotechnique 2014, 64, 1010-1013. [CrossRef]

18. Nayanthara, P.G.N.; Dassanayake, A.B.N.; Nakashima, K.; Kawasaki, S. Microbial induced carbonate precipitation using a native inland bacterium for beach sand stabilization in nearshore areas. Appl. Sci. 2019, 9, 3201. [CrossRef]

19. Imran, M.; Kimura, S.; Nakashima, K.; Evelpidou, N.; Kawasaki, S. Feasibility study of native ureolytic bacteria for biocementation towards coastal erosion protection by micp method. Appl. Sci. 2019, 9, 4462. [CrossRef]

20. Liu, K.W.; Jiang, N.J.; Qin, J.; De Wang, Y.J.; Tang, C.S.; Han, X.L. An experimental study of mitigating coastal sand dune erosion by microbial- and enzymatic-induced carbonate precipitation. Acta Geotech. 2020, 1-14. [CrossRef]

21. Shahin, M.A.; Jamieson, K.; Cheng, L. Microbial-induced carbonate precipitation for coastal erosion mitigation of sandy slopes. Géotechnique Lett. 2020, 10, 211-215. [CrossRef]

22. Daryono, L.R.; Nakashima, K.; Kawasaki, S.; Suzuki, K.; Suyanto, I.; Rahmadi, A. Investigation of natural beachrock and physical-mechanical comparison with artificial beachrock induced by micp as a protective measure against beach erosion at yogyakarta, Indonesia. Geosciences 2020, 10, 143. [CrossRef]

23. Crowley, R.; Davies, M.; Ellis, T.N.; Hudyma, N.; Ammons, P.; Matemu, C. Microbial induced calcite precipitation of dune sand using a surface spray technique. In Geotechnical Special Publication; American Society of Civil Engineers (ASCE): Reston, VA, USA, 2019; pp. 213-222.

24. Carmona, J.P.S.F.; Venda Oliveira, P.J.; Lemos, L.J.L.; Pedro, A.M.G. Improvement of a sandy soil by enzymatic calcium carbonate precipitation. Proc. Inst. Civ. Eng. Geotech. Eng. 2018, 171, 3-15. [CrossRef]

25. Huang, P.M.; Bollag, J.-M.; Senesi, N. Interactions between Soil Particles and Microorganisms: Impact on the Terrestrial Ecosystem, 1st ed.; John Wiley \& Sons: Hoboken, NJ, USA, 2002; ISBN 978-0471607908.

26. Van Paassen, L.A. Biogrout Ground Improvement by Microbial Induced Carbonate Precipitation. Ph.D. Thesis, Delft University of Technology, Mekelweg, The Netherlands, 2009.

27. Zuddas, P.; Mucci, A. Kinetics of calcite precipitation from seawater: I. A classical chemical kinetics description for strong electrolyte solutions. Geochim. Cosmochim. Acta 1994, 58, 4353-4362. [CrossRef]

28. Zuddas, P.; Mucci, A. Kinetics of calcite precipitation from seawater: II. The influence of the ionic strength. Geochim. Cosmochim. Acta 1998, 62, 757-766. [CrossRef]

29. López, D.; Vlamakis, H.; Losick, R.; Kolter, R. Cannibalism enhances biofilm development in bacillus subtilis. Mol. Microbiol. 2009, 74, 609-618. [CrossRef] [PubMed]

30. Ries, J.B.; Anderson, M.A.; Hill, R.T. Seawater Mg/Ca controls polymorph mineralogy of microbial $\mathrm{CaCO}_{3}$ : A potential proxy for calcite-aragonite seas in Precambrian time. Geobiology 2008, 6, 106-119. [CrossRef] [PubMed]

31. Loste, E.; Wilson, R.M.; Seshadri, R.; Meldrum, F.C. The role of magnesium in stabilising amorphous calcium carbonate and controlling calcite morphologies. J. Cryst. Growth 2003, 254, 206-218. [CrossRef]

32. Chave, K.E. Aspects of the Biogeochemistry of Magnesium 1. Calcareous Marine Organisms. J. Geol. 1954, 62, 266-283. [CrossRef] 
33. Khodadadi Tirkolaei, H. Primary Study on Ureolysis Based Microbially Induced Calcium Carbonate Precipitation Technique For Geotechnical Applications. Ph.D. Thesis, Eastern Mediterranean University, Gazimağusa, North Cyprus, 2016.

34. Cheng, L.; Shahin, M.A.; Mujah, D. Influence of key environmental conditions on microbially induced cementation for soil stabilization. J. Geotech. Geoenviron. Eng. 2017, 143, 04016083. [CrossRef]

35. Frankenberger, W.T., Jr.; Bingham, F.T. Influence of salinity on soil enzyme activities. Soil Sci. Soc. Am. J. 1982, 46, 1173-1177. [CrossRef]

36. ASTM D6913/D6913M-17. Standard Test Methods for Particle-Size Distribution (Gradation) of Soils Using Sieve Analysis; ASTM International: West Conshohocken, PA, USA, 2017; Available online: www.astm.org (accessed on 28 September 2020).

37. JIS A 1224. Test Method for Minimum and Maximum Densities of Sands; Japanese Geotechnical Society: Tokyo, Japan, 2014.

38. STM D2487-17e1. Standard Practice for Classification of Soils for Engineering Purposes (Unified Soil Classification System); ASTM International: West Conshohocken, PA, USA, 2017; Available online: www.astm.org (accessed on 28 September 2020).

39. Khodadadi, T.H.; Javadi, N.; Krishnan, V.; Hamdan, N.; Kavazanjian, E., Jr. Crude urease extract for biocementation. J. Mater. Civ. Eng. 2020, 32, 04020374. [CrossRef]

40. Dickinson, S.R.; McGrath, K.M. Quantitative determination of binary and tertiary calcium carbonate mixtures using powder X-ray diffraction. Analyst 2001, 126, 1118-1121. [CrossRef]

41. Hadiko, G.; Han, Y.S.; Fuji, M.; Takahashi, M. Effect of magnesium ion on the precipitation of hollow calcium carbonate by bubble templating method. Key Eng. Mater. 2006, 317-318, 65-68. [CrossRef]

42. Fernández-Díaz, L.; Fernández-González, Á.; Prieto, M. The role of sulfate groups in controlling $\mathrm{CaCO}_{3}$ polymorphism. Geochim. Cosmochim. Acta 2010, 74, 6064-6076. [CrossRef]

43. Chakrabarty, D.; Mahapatra, S. Aragonite crystals with unconventional morphologies. J. Mater. Chem. 1999, 9, 2953-2957. [CrossRef]

44. White, W.B. Speleothem microstructure/speleothem ontogeny: A review of Western contributions. Int. J. Speleol. 2012, 41, 329-358. [CrossRef]

(C) 2020 by the authors. Licensee MDPI, Basel, Switzerland. This article is an open access article distributed under the terms and conditions of the Creative Commons Attribution (CC BY) license (http://creativecommons.org/licenses/by/4.0/). 